\title{
REFLECTIONS
}

\section{Five Careers and Eight Airplanes: An Oral History of John Geyman, MD}

\author{
Jobn J. Frey III, MD \\ Department of Family Medicine, University \\ of Wisconsin School of Medicine and Pub- \\ lic Health, Madison, Wisc

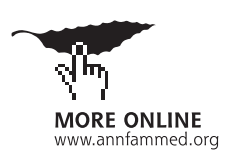

Conflict of interest: none reported

\section{CORRESPONDING AUTHOR}

John J. Frey III, MD

Department of Family Medicine

School of Medicine and Public Health

University of Wisconsin

777 S. Mills St

Madison, WI 53715

jfrey@fammed.wisc.edu

\begin{abstract}
Each generation has an obligation to remind succeeding ones about the people, ideas, and events that have gotten us to this point. This essay and an accompanying oral history trace the origins of family medicine through the life of someone who helped found it-John P. Geyman, MD. He is one of the most published family physicians in the United States. In addition to being a rural family physician, he was one of the first residency directors in family medicine and the first editor of the discipline's first academic journal. His career weaves 4 themes together in interesting and creative ways: commitment to the work of clinical practice, a sense of responsibility for strengthening clinical education, a belief that clinical care should be based on science and delivered within a rational system of health care, and a love of flying. His story also exemplifies the generation of general practitioners who started family medicine but who retained both a personal understanding of the complex nature of independent practice and a reliance on community.
\end{abstract}

Ann Fam Med 2007;5:368-370. DOI: 10.1370/afm.717.

\section{INTRODUCTION}

$\mathrm{O}$ ccasionally, when I talk with younger colleagues about a person or article or an event that was formative in the academic discipline of family medicine, I can see in their faces that I am talking about something with which they have no personal experience. Each generation has an obligation to remind succeeding ones about the people, ideas, and events that have gotten us to this point. A quote attributed to Roger Shattuck, Jr, in the New York Times stated, "Everything has been said. But nobody listens. Therefore, it has to be said all over again-only better. In order to say it better, we have to know how it was said before."1 This essay and the accompanying Supplemental Oral History (available online-only at http://www.annfammed.org/cgi/content/full/5/4/368/ DC1) are about saying it all over again.

John P. Geyman, MD, is one of the most published family physicians in the United States, having published more than 160 journal articles and 10 books, 5 since retiring as chair at the University of Washington Department of Family Medicine. He was graduated from medical school at the University of California, San Francisco, and began practice in $\mathrm{Mt}$ Shasta, a rural community in Northern California, after 2 years of general practice training in Santa Rosa, Calif. John was among the first residency directors in the discipline, beginning at Santa Rosa in 1969, when the first 16 residency programs were approved in family practice, and Santa Rosa, a converted general practice residency, became 1 of those 16 .

In 1974 John became the first editor of the first academic journal in family medicine when he and a group of colleagues started The Journal of Family Practice (JFP). Before that time, there were no refereed journals with original research by family physicians. He continued as editor of JFP until 1990, 
when he became editor of the Journal of the American Board of Family Practice. In 2003 he stepped down as editor of that journal. During his 29 years as a journal editor, he had an influence on the published literature in an academic discipline that may be unequaled in US history. Most active academic family physicians have had at least 1 rejection letter from John during our careers!

From 1971 to 1972, John spent time at the University of Utah in the Division of Family Practice; after 1972, at the University of California-Davis, he was in charge of developing a network of residency programs in Northern California. In 1976, he became chair of the University of Washington Department of Family Medicine after the founding chair, Ted Phillips, MD, $\mathrm{MPH}$, stepped down. The University of Washington expanded its educational activities through the WWAMI (Washington, Wyoming, Alaska, Montana, Idaho) program and grew its biomedical research as well, becoming the top-rated family medicine school, as well as one of the top 10 National Institutes of Health-funded medical schools. John left the chair at UW in 1990 and for the next 7 years returned to rural practice on an island in Puget Sound. He retired from clinical practice when he was 66 years old. He and his wife, Gene, have been married for more than 50 years and have lived part or full time on San Juan Island in the Strait of Juan de Fuca since the late 1980s.

By 2000, John was increasing his involvement with Physicians for a National Health Plan, a national organization of physicians working for comprehensive health care in the United States. He served as the president of that organization in 2005 and 2006, and he has published 4 books on the health system in the United States. ${ }^{2-5}$ He was elected to the Institute of Medicine of the National Academy of Sciences and is a recipient of the F. Marian Bishop Award of the Society of Teachers of Family Medicine.

Four themes emerge from the interviews that comprise John's online Supplemental Oral History: his commitment to the work of clinical practice, his sense of responsibility for strengthening clinical education, his belief that clinical care should be based on science and delivered within a rational system of health care, and his love of flying. His 46 -year career weaves those themes together in interesting and creative ways.

For example, early in his career he saw that his small community needed a more organized way to do acute cardiac care. He flew to San Francisco to train to establish a coronary care unit in his community hospital, then implemented the unit and reported its effects in the medical literature. ${ }^{6}$ Later in his career, when he realized the island where he worked needed an effective way of responding to emergency situations, he organized an emergency medical technician (EMT) program, which subsequently saved his own life. Of course, he wrote that up and published it as well. ${ }^{7}$

His story also exemplifies the generation of general practitioners who started family medicine but who retained both a personal understanding of the complex nature of independent practice and a reliance on community. Some who left practice in their late 30 s and early 40 s to become faculty members were fleeing what was for them a practice that was becoming increasingly impossible to manage. They felt they had to find a different way for general practice. Others, such as John, wanted to be a part of an untested idea they believed would transform medical education to be more relevant to the needs of society.

John never emotionally left the small town, and he used his rural practice experience as a personal benchmark for practice and scholarship that helped him explore general practice and family medicine at a deep and personal level. His family didn't sell their house in Mt Shasta until 15 years after they had left, and they continued to get the weekly county newspaper for 20 years. Most revealing, perhaps, is that, after a 30 -year career in academic leadership, he spent the last 7 years of his practicing career again in a small community practice.

John has managed to squeeze, depending on how one counts, at least 5 careers and 8 airplanes into his life so far. His books on flying and his books on family medicine and the health care system in the United States all have some of the same literary style: a personal voice that does not overwhelm the facts and ideas that he is trying to convey. He exercises a diligence in looking for information wherever and from whomever he can find it, and he analyzes and organizes that information in a way he thinks will be helpful to the reader. He also conveys the pleasure he gets both from writing the book and doing the work, be it family doctoring, critiquing the health care system in the United States, or flying a small plane.

In 2001, on his 70th birthday, John had a myocardial infarction and cardiac arrest while swimming laps and was successfully resuscitated by the EMT group he had helped train. Nine months after surgery and cardiac rehabilitation, he was allowed to fly again, but the Federal Aviation Administration required follow-up tests every 6 months for 3 years. During that time of monitoring, he decided to find and purchase an opencockpit biplane. He did find one and flew it, solo, home to Washington from central Texas. As he says: "Low and slow type flying has always been my goal_ good old stick and rudder without too much gadgetry." He, of course, wrote a book chronicling the story. ${ }^{8}$

I spent 2 days interviewing John at his home in June 2006 for the oral history. He had been kind 
enough to pick me up in his single engine "tail dragger" at the mainland airport nearest to his home on the San Juan Island and then flew me back the next day. After he dropped me off, I realized that I had forgotten my passport and some files at his house. I called and explained the situation apologetically. "No problem," John said, "I'll be right over."

So when I heard the small plane circling to land, I suspected that John might have taken my forgetfulness as a chance to fly his biplane, and I was right. We spent another hour talking and then he headed back. He climbed into the cockpit, did his preflight check, started the engine, and taxied off, at the age of 75 years, to experience the wind and the sun over the Puget Sound. I looked out to see him, in his leather flight helmet, ear phones, and aviator glasses, taxiing toward the runway, waving and smiling, focusing on what was next, starting another chapter.

The story of John's career, thus far (as he would put it) is garnered from a series of oral histories by William Ventres, MD, in 1989, Fitzhugh Mullan, MD, MPH, in 1996, my own conversations with him, and from the books and articles he has published over a 37-year academic career.
To read or post commentaries in response to this article, see it online at http://www.annfammed.org/cgi/current/full/5/4/368.

Key words: Personal narratives; history; family practice; essays

Submitted February 24, 2007; submitted revised March 30, 2007; accepted April 9, 2007.

\section{References}

1. Martin D. Rogert Shattuck, scholar, is dead at 82. NY Times. December 10, 2005:A19.

2. Geyman J. Health Care in America: Can Our Ailing System be Healed? Boston, Mass: Butterworth-Heineman Medical /Elsevier; 2001.

3. Geyman J. Falling Through the Safety Net: Americans Without Health Insurance. Monroe, ME: Common Courage Press; 2003.

4. Geyman J. The Corporate Transformation of Health Care: Can the Public Interest Still Be Served? New York, NY: Springer Publishing; 2004.

5. Geyman J. Shredding the Social Contract: The Privatization of Medicare. Monroe, ME: Common Courage Press; 2006.

6. Geyman JP. A coronary care unit in a 25-bed rural hospital. Calif Med. 1970;112(1):74-77.

7. Killien SY, Geyman JP, Gossom JB, Gimlett D. Out-of-hospital cardiac arrest in a rural area: a 16-year experience with lessons learned and national comparisons. Ann Emerg Med. 1996;28(3):294-300.

8. Geyman J. An Open Cockpit Biplane Dream: Honey Bee III. Friday Harbor, WA: Avian Ridge Books; 2005. 